\title{
Examination of Periodontal Status in Chronic Obstructive Pulmonary Disease Greek Adults: A Case - Control Study
}

\author{
Nikolaos Andreas Chrysanthakopoulos ${ }^{1 *}$, Aggelos Antonios Oikonomou ${ }^{2}$ \\ ${ }^{l}$ Dental Surgeon (DDSc), -Oncologist (MSc Oncol), Specialized in Clinical Oncology, Cytology and \\ Histopathology, Dept.of Pathological Anatomy, Medical School, University of Athens, Athens, Greece -PhD \\ in Oncology (cand) -Resident in Maxillofacial and Oral Surgery, 401 General Military Hospital of Athens, \\ Athens, Greece \\ ${ }^{2}$ Medical Doctor MD, Private Practice, Patra, Greece
}

*Corresponding Author: Nikolaos Andreas Chrysanthakopoulos, 35, Zaimi Street, PC 26 223, Patra, Greece.

\begin{abstract}
Aim: The aim of the current research was to assess the possible differences regarding the periodontal status between individuals suffering from chronic obstructive pulmonary disease (COPD) compared with healthy individuals.

Materials and Methods: 453 individuals with COPD and 997 matching healthy controls were interviewed and oral clinically examined. The indices used to determine the periodontal status for cases and controls included Probing Pocket Depth (PPD), Clinical Attachment Loss (CAL) and Bleeding on Probing (BOP). Chi-square test and logistic regression models were carried out to assess the data.

Results: COPD patients showed worst periodontal parameters among some of the indices examined such as $\operatorname{PPD}(p=0.001)$, tooth-brushing frequency $(p=0.045)$ and dental check-up $(p=0.048)$, after adjustment for smoking and socio-economic status.

Conclusions: Probing Pocket Depth and oral hygiene parameters such as tooth-brushing frequency and dental check-up were statistically significant different between individuals who were suffered from COPD and healthy ones.
\end{abstract}

Keywords: Chronic obstructive pulmonary disease; Periodontal disease; Adults; Risk factors

\section{INTRODUCTION}

Chronic Obstructive Pulmonary Disease (COPD) is one of the most common respiratory diseases the $4^{\text {th }}$ leading cause of death in the world, and it is predicted that by 2020 will be the $3^{\text {rd }}$ leading cause of death and the $5^{\text {th }}$ leading cause of overall disability worldwide [1]. COPD is a heterogeneous respiratory disease that includes clinical conditions such as emphysema, chronic bronchitis, small airways disease, and non-reversible asthma [2]. Its prevalence in Europe and North America and is 9\% to $10 \%$ in adults aged 40 years or older, its increased prevalence has been attributed to increased smoking rates, whereas COPD is impaired by exacerbations possibly due to viral or bacterial infections [3].

COPD's etiology implicates genetic, behavioral and environmental risk factors [4]. The main genetic risk factor is a severe hereditary deficiency of a1-antitrypsin, a circulating serine proteases inhibitor, whereas other possible genetic factors that are involved in COPD pathogenesis have not been yet determined [5, $6]$. It is possible that various genes and an interaction between genes and environment are involved in COPD pathogenesis [7]. The environmental and behavioral risk factors which contribute to COPD development are exposure to cigarette and passive cigarette smoke $[8,9]$, occupational chemicals, such as organic and inorganic chemical fumes and agents [10], indoor and outdoor air and atmospheric pollution, despite the fact that the role of outdoor air pollution in COPD pathogenesis remains unclear $[11,12]$. An interesting observation is that not all cigarette smokers develop clinically significant COPD, suggesting that genetic factors may modify each individual's risk [13]. Moreover, it remains unclear why individuals-never smokers develop 
COPD [14]. Socio-economic status (SES) is involved in COPD pathogenesis as it has been observed that the onset of COPD is inversely associated with SES [15] however, it is unclear whether SES is associated with the mentioned pollutants or other unknown factors that are associated with low SES [16].

As already mentioned COPD is a heterogeneous disease that is characterized by progressive airflow obstruction and chronic airways inflammation, whereas the abnormal inflammatory response of the lung leads to airflow limitation [17]. The chronic airways inflammation is accompanied by increased levels of specific inflammatory cells at different locations of the lung, whereas, it has been detected lung tissue remodeling as a result of the repeated processes of lung tissues injury and repair [18].

Periodontal Disease [PD] and especially periodontitis is a progressive inflammation, which leads to destruction of periodontal tissue. PD is highly prevalent and may affect up to $90 \%$ of the world population [19]. Chronic periodontitis is characterized by an increased plasma concentration of inflammatory cytokines and chemokines, such as $\mathrm{C}$ reactive protein [Crp], Interleukin [IL]-1 and -6 , that are associated with PD severity. The possible role of those inflammatory biomarkers in several systemic diseases development could be attributed to a general inflammatory reaction, a systemic immune reaction to periodontal pathogens or the entry of periodontal pathogens into the blood circulation $[20,21]$. Thus, many reports have investigated a possible role of periodontitis as a risk factor for systemic diseases or disorders [22], including COPD [2337]. A possible link between PD and COPD has been suggested, based on the fact that chronic periodontitis is associated with increased concentration of inflammatory mediators and because of evidence involving chronic inflammation in COPD pathogenesis. Moreover, oral pathogens and inflammatory cytokines and chemokine from damaged periodontal tissue induce a systemic inflammation, which may contribute to COPD pathogenesis [38-40].

COPD and periodontitis have in common pathogenic pathways such as a chronic course with progressive and irreversible tissue destruction caused by neutrophilic inflammation with subsequent proteolytic destruction of connective tissues, gradual loss of normal organ function and share known risk factors such as age, tobacco smoking, SES, and living conditions [38, 39]. It is obvious that an association exists between both pathological conditions as periodontitis appears to be a risk factor for COPD development and periodontal pathogens may play a key role in COPD pathogenesis. In contrast to the mentioned researches, few surveys have investigated whether the periodontal status of individuals who suffer from COPD is worse than that of the non-COPD individuals, where as their findings were inconsistent, some even contradictory [41, 42]. The reasons were that those studies used different population samples and PD indices. The aim of the current report was to assess the possible differences in periodontal condition between individuals who suffered from COPD diagnosed by clinical examinations and healthy ones.

\section{Material AND Methods}

\subsection{Study Sample}

From March 2019 to October 2020, a casecontrol study was carried out in which a total of 453 individuals who suffered from COPD, 296 males and 157 females, and 997 controls with normal pulmonary function, 409 males and 588 females, aged 35-78 years, were recruited from 3 private practices.

All COPD cases were clinically diagnosed and confirmed by lung function examination for more than three years. Criteria used for the diagnosis of COPD based on the Global Initiative for Chronic Obstructive Lung Disease [GOLD] spirometry guidelines. Lung function was examined and assessed using spirometry. The lung function measurements were assessed by the physicians of the patients and recorded on their medical files. During at least 5 forced expirations, the physician attempted to obtain 3 acceptable spirograms, at least two of which showed similar results for the Forced Expiratory Volume [FEV]/1sec [FEV1] and Forced Vital Capacity (FVC). Air limitation was set using the fixed ratiopost-bronchodilatorFEV1/FVC $<0.70$ [4].COPD patients and controls should meet the following selection criteria: no having fever, worsening of respiratory symptoms, acute pulmonary diseases or medication change within the last month, no having history of lung volume reduction surgery, pneumonectomy, or lung transplantation, no having history of any periodontal treatment in the last 6 months, had not received systemic antibiotic treatment or a systematic treatment with glucocorticoids or immunosuppression agents within the previous 
6 months [43], aged 35 years and up with $\geq$ 15 teeth and periodontitis from stage I to IV [44].They also should not be suffered from diseases such as cardiovascular disease, diabetes mellitus, rheumatoid arthritis, or any type of malignancies. Those pathological conditions could have potential effects on the periodontal tissues as confounders and could lead to biased secondary associations.

Controlling for the potential confounding effect of smoking and SES, based on the control selection which carried out by the friendly and collegial environment of healthy individuals, and both groups were matched for gender and age. Moreover, cases and controls were selected from the same city population in an effort to select a representative study sample and to avoid or eliminate possible selection biases. Therefore, control group was selected from individuals who were presented to routine health follow-up at the mentioned practices, between 2019 and 2020.

\subsection{Dental and Oral Clinical Examination}

Cases and controls underwent an oral and dental clinical examination by a well-trained and calibrated dentist regarding the mentioned periodontitis indices PPD, CAL and BOP, and responded to a medical and dental health questionnaire. All indices examined were measured with a millimeter graduated probe [Hu-Friedy PCP 10-SE] at four sites per tooth [mesio-buccal, disto-buccal, mesio-lingual, and disto-lingual] in all quadrants and the worst values of the indices recorded to the nearest 1.0 $\mathrm{mm}$. Remaining roots and 3rd molars were excluded.

The criteria for assessing periodontitis indices, PPD and CAL, were based on the new classification as already mentioned, whereas BOP, was recorded as present or not within 30 seconds following probing with gentle pressure at four sites per tooth [45]. PPD index was dichotomously assessed as code 0 : stage I [maximum $\mathrm{PPD} \leq 4.0 \mathrm{~mm}$ ] and code 1: stage IIIV $[\mathrm{PPD} \leq 4.0-\geq 6.0 \mathrm{~mm}$ ]. Similarly CAL severity, was assessed as code 0: stage I [CAL: 1.0-2.0 mm], and code 1: stage II-IV [CAL: $3.00-\geq 5.0 \mathrm{~mm}$ ] [44]. BOP absence was assessed as code 0 and presence as code 1 , respectively [45]. The same dentist re-examined a random sample of 300 [ 20.0\%] cases and controls, after a period of 3 weeks for assessing the intra-examiner reliability and no differences were found between both oral clinical examinations [Cohen's Kappa=0.94)] whereas during that time period no oral hygiene instructions were given to the participants.

\subsection{Ethical Consideration}

The current study was not an experimental study and should not reviewed and approved by autheorized committees [Ministry of Health, Dental Associations, etc.] in Greece. The individuals who agreed to participate in the present study signed an informed consent form.

\subsection{Statistical Analysis}

The worst values of PPD and CAL at four sites per tooth for cases and controls were assessed. Females, non-smokers, low socioeconomic status [income/monthly equivalent to or less than $1,000 €$ ], low educational level [graduated from Elementary/High School], irregular daily tooth- brushing daily $[\leq 1 /$ daily] and annual dental check-up $[\leq 1 /$ year], and controls were coded as 0 . Age groups distribution was coded as $0,1,2$, and 3 for ages $35-49,50-59,60-69$ and $70+$, respectively. The univariate analysis model was carried out to estimate the associations between the independent parameters examined and cases/controls, separately. Multivariate logistic regression analysis was performed to assess the associations between the dependent variable, COPD, and independent ones using the Enter and Stepwise methods. Unadjusted and Adjusted Odds Ratios [OR's] and 95\% [Confidence Interval] CI were also estimated. The statistical method Cohran's and MantelHaenszel's was applied to control possible confounders, such as smoking. Statistical analysis was performed by SPSS statistical package [SPSS PC19.0, SPSS, Inc., Chicago, IL, USA], and a $p$ value less than $5 \%$ [p< 0.05] was considered to be statistically significant.

\section{Results}

Chi-squared test was used to compare characteristics between cases and controls for categorical variables. The results of univariate analysis are presented in Table1, in which low SES, smoking, irregular daily tooth-brushing and annual dental check-up, and deep periodontal pockets were found to be statistically significant different between cases and controls. The same table shows unadjusted OR's and 95\% CI. According to regression model, the 1a step showed that smoking $(\mathrm{p}=$ $0.000)$ and deep periodontal pockets $(\mathrm{p}=0.006)$ were significantly different between COPD patients and controls, whereas irregular annual dental check-up was marginally significantly 
Examination of Periodontal Status in Chronic Obstructive Pulmonary Disease Greek Adults: A Case Control Study

different between individuals examined $(\mathrm{p}=0.054)$ (Table 2). The same table shows adjusted OR's and 95\% CI. The final model (step 6a), showed that all the mentioned indices were statistically significant different between
COPD patients and healthy individuals.PPD was also statistically significant different between cases and controls after adjusting for smoking and SES (Table 3).

Table1. Univariate analysis of cases and controls regarding each independent variable examined

\begin{tabular}{|c|c|c|c|c|c|c|}
\hline \multicolumn{2}{|c|}{ Variables } & $\begin{array}{c}\text { Cases } \\
(\text { no) }(\%)\end{array}$ & $\begin{array}{l}\text { Controls } \\
(\text { no) }(\%)\end{array}$ & p-value & $\begin{array}{c}\text { Odds Ratio } \\
\text { (OR) }\end{array}$ & $\begin{array}{c}\text { 95\% Confidence } \\
\text { Interval (CI) } \\
\end{array}$ \\
\hline Gender: & $\begin{array}{l}\text { Males } \\
\text { Females }\end{array}$ & $\begin{array}{l}296(65.3) \\
157(34.7)\end{array}$ & \begin{tabular}{|c}
$409(41.0)$ \\
$588(59.0)$
\end{tabular} & $0.000 *$ & 0.37 & $0.29-0.47$ \\
\hline Age (years): & $\begin{array}{r}35-49 \\
55-59 \\
60-69 \\
70+\end{array}$ & $\begin{array}{l}45(9.9) \\
198(43.7) \\
152(33.6) \\
58(12.8)\end{array}$ & \begin{tabular}{|c}
$118(11.8)$ \\
$409(41.0)$ \\
$338(33.9)$ \\
$132(13.3)$
\end{tabular} & 0.661 & - & - \\
\hline Socio-econo & $\begin{array}{l}\text { nic level: } \\
\text { Low } \\
\text { High }\end{array}$ & $\begin{array}{l}321(70.9) \\
132(29.1)\end{array}$ & $\begin{array}{l}506(50.8) \\
491(49.2)\end{array}$ & $0.000 *$ & 2.36 & $1.86-3.00$ \\
\hline Educational & $\begin{array}{l}\text { evel: } \\
\text { Low } \\
\text { High }\end{array}$ & $\begin{array}{c}260(57.4) \\
193(42.6)\end{array}$ & $\begin{array}{l}568(57.0) \\
429(43.0)\end{array}$ & 0.880 & 1.02 & $0.81-1.27$ \\
\hline Smoking: & $\begin{array}{l}\text { No } \\
\text { Yes }\end{array}$ & $\begin{array}{r}91(20.1) \\
362(79.9)\end{array}$ & $\begin{array}{c}519(52.1) \\
478(47.9)\end{array}$ & $0.000 *$ & 0.23 & $0.18-0.30$ \\
\hline \begin{tabular}{|l|} 
Tooth-brush \\
\end{tabular} & $\begin{array}{r}\text { frequency: } \\
\leq 1 / \text { daily } \\
\geq 2 \text { /daily }\end{array}$ & $\begin{array}{l}287(63.4) \\
166(36.6) \\
\end{array}$ & $\begin{array}{c}488(48.9) \\
509(51.1)\end{array}$ & $0.000 *$ & 1.80 & $1.44-1.27$ \\
\hline \begin{tabular}{|l} 
Dental follov \\
\end{tabular} & $\begin{array}{l}\text {-up: } \\
\leq 1 \text { /annually } \\
\geq 2 \text { /annually }\end{array}$ & $\begin{array}{l}306(67.5) \\
147(32.5) \\
\end{array}$ & $\begin{array}{l}465(46.6) \\
532(53.4) \\
\end{array}$ & $0.000 *$ & 2.38 & $1.89-3.00$ \\
\hline $\begin{array}{r}\text { Periodontal p } \\
\text { De } \\
\text { Depth } \leq 4\end{array}$ & $\begin{array}{l}\text { ockets: } \\
\text { pth } \leq 4.0 \mathrm{~mm} \\
.0-\geq 6.0 \mathrm{~mm}\end{array}$ & $\begin{array}{l}65(14.3) \\
388(85.7)\end{array}$ & $\begin{array}{c}381(38.2) \\
616(61.8)\end{array}$ & $0.000 *$ & 0.27 & $0.20-0.36$ \\
\hline CAL: & $\begin{array}{l}1-2.0 \mathrm{~mm} \\
0-\geq 5.0 \mathrm{~mm}\end{array}$ & $\begin{array}{l}115(25.4) \\
338(74.6)\end{array}$ & $\begin{array}{c}301(30.2) \\
696(69.8)\end{array}$ & 0.061 & 0.78 & $0.61-1.01$ \\
\hline BOP: & $\begin{array}{l}\text { No } \\
\text { Yes }\end{array}$ & $\begin{array}{l}173(38.2) \\
280(61.8)\end{array}$ & $\begin{array}{c}364(36.5) \\
633(63.5)\end{array}$ & 0.539 & 1.07 & $0.85-1.35$ \\
\hline
\end{tabular}

Table2. Presentation of association between parameters examined and COPD according to Enter (first step- $1^{a}$ ) and Wald (final step-6a) methods of Multivariate Logistic Regression Analysis Model

\begin{tabular}{|c|c|c|c|c|c|c|c|c|c|}
\hline \multicolumn{10}{|c|}{ Variables in the Equation } \\
\hline & & \multirow[b]{2}{*}{ B } & \multirow[b]{2}{*}{ S.E. } & \multirow[b]{2}{*}{ Wald } & \multirow[b]{2}{*}{ df } & \multirow[b]{2}{*}{ Sig. } & \multirow[b]{2}{*}{$\operatorname{Exp}(B)$} & \multicolumn{2}{|c|}{$95 \%$ C.I. for EXP (B) } \\
\hline & & & & & & & & Lower & Upper \\
\hline \multirow[t]{10}{*}{ Step $1^{\mathrm{a}}$} & gender & ,629 &, 152 & 3,224 & 1 &, 080 & 1,876 & 1,394 & 2,525 \\
\hline & socioecon.stat & 277 &, 171 & 2,630 & 1 &, 105 & ,758 &, 543 & 1,059 \\
\hline & educat.level &, 189 &, 171 & 1,231 & 1 &, 267 & 1,208 & ,865 & 1,688 \\
\hline & smok.stat & 2,933 &, 158 & 14,444 & 1 &, $000 *$ & 6,779 & 3,777 & 9,596 \\
\hline & toothbr.freq & ,468 &, 153 & 4,398 & 1 & ,062 & 1,026 & ,464 & 1,845 \\
\hline & dent.checkup & ,690 &, 149 & 7,430 & 1 &, 054 & 1,994 & 1,489 & 2,670 \\
\hline & prob.pock.depth & 1,615 & ,214 & 9,152 & 1 &, $006^{*}$ & 3,026 & 1,802 & 6,651 \\
\hline & clin.attach.loss &, 179 &, 235 & 578 & 1 &, 447 & ,836 & ,528 & 1,326 \\
\hline & bleed.on.prob & ,281 & ,209 & 1,805 & 1 &, 179 & 1,325 & ,879 & 1,996 \\
\hline & Constant & 3,996 &, 270 & 18,580 & 1 &, 000 & ,018 & & \\
\hline \multicolumn{10}{|c|}{$\begin{array}{l}\text { a. Variable(s) entered on step 1: gender, socioeconomic status, educat.level, smoking status, tooth br.freq, } \\
\text { dent.checkup, prob.pock.depth, clin.attach.loss, bleed.on.prob } \\
* \text { p-value : statistically significant }\end{array}$} \\
\hline
\end{tabular}


Examination of Periodontal Status in Chronic Obstructive Pulmonary Disease Greek Adults: A Case Control Study

Table3. Presentation $n$ of Association between Independent Variables and COPD According to Wald (final step- $\left.6^{a}\right)$ Method of Multivariate Logistic Regression Analysis Model

\begin{tabular}{|c|c|c|c|c|c|c|c|c|c|}
\hline \multicolumn{10}{|c|}{$\mathbf{X}$} \\
\hline & & \multirow[t]{2}{*}{ B } & \multirow[t]{2}{*}{ S.E. } & \multirow[t]{2}{*}{ Wald } & \multirow[t]{2}{*}{ df } & \multirow[t]{2}{*}{ Sig. } & \multirow[t]{2}{*}{$\operatorname{Exp}(B)$} & \multicolumn{2}{|c|}{$\begin{array}{l}95 \% \text { C.I. for } \mathrm{EXP} \\
\text { (B) }\end{array}$} \\
\hline & & & & & & & & Lower & Upper \\
\hline \multirow{5}{*}{ Step $6^{\mathrm{a}}$} & smok.stat & 2,921 &, 155 & 17,057 & 1 &, $000 *$ & 8,557 & 4,706 & 12,123 \\
\hline & toothbr.freq &, 419 &, 150 & 6,855 & 1 &, $045^{*}$ & 1,658 &, 490 & 2,082 \\
\hline & dent.checkup & ,705 &, 146 & 7,520 & 1 &, $048 *$ & 2,024 & 1,513 & 2,909 \\
\hline & prob.pock.depth & 1,626 &, 179 & 9,740 & 1 &, $001 *$ & 4,083 & 2,576 & 7,226 \\
\hline & Constant & 3,965 & 237 & 19,656 & 1 &, 000 & ,019 & & \\
\hline
\end{tabular}

\section{DISCUSSION}

Few epidemiological studies have investigated whether the periodontal status, expressed by clinical indices and tooth loss, of the COPD patients is worse than that of the non-COPD individuals and the findings available were inconsistent, some even contradictory, based on previous studies [41, 42]. The main reason is that there are still a lack of specialized metaanalyses that quantitatively compare the periodontal status between the COPD and nonCOPD subjects by evaluating the related clinical periodontal indexes.

The most common indices for assessing periodontal status are PPD, CAL, BOP, Gingival Index (GI), Bleeding Point Index,
Plaque Index (PI), Alveolar Bone Loss (ABL), etc. [46]. The current case-control study, showed that COPD patients appeared to have poor periodontal status as reflected by deeper periodontal pockets-PPD and oral hygiene parameters than controls with normal pulmonary function.

The outcomes showed that PPD was statistically significant different between COPD patients and healthy individuals. That significant difference remained after adjusting for covariates such as smoking and SES (Table 4). PPD is a crucial index for assessing the severity of PD and refers to the long-term stages of chronic inflammation including destructive processes signs of a chronic inflammatory response [47].

Table4. Application of Cohran's and Mantel-Haenszel's statistical method for controlling possible confounders

\begin{tabular}{|c|c|c|}
\hline Variables & $\operatorname{Exp}(B)$ & $95 \% \mathrm{CI}$ \\
\hline \multicolumn{3}{|l|}{ Probing pocket depth } \\
\hline Non - smokers & 2.156 & $1.533-3.770$ \\
\hline Smokers & 6.145 & $3.108-9.280$ \\
\hline \multicolumn{3}{|l|}{ Probing pocket depth } \\
\hline Socioeconomic status: Low & 1.385 & $0.410-1.829$ \\
\hline $\begin{array}{r}\text { High } \\
\end{array}$ & 1.106 & $0.364-1.617$ \\
\hline \multicolumn{3}{|l|}{ Daily tooth-brushing } \\
\hline Non - smokers & 1.088 & $0.223-1.135$ \\
\hline Smokers & 1.117 & $0.504-1.231$ \\
\hline \multicolumn{3}{|l|}{ Daily tooth-brushing } \\
\hline Socioeconomic status: Low & 1.567 & $0.572-1.904$ \\
\hline High & 1.424 & $0.515-1.782$ \\
\hline \multicolumn{3}{|l|}{ Annual dental check-up } \\
\hline Non - smokers & 1.658 & $0.778-1.871$ \\
\hline Smokers & 1.788 & 0.823-1.998 \\
\hline \multicolumn{3}{|l|}{\begin{tabular}{|l} 
Annual dental check-up \\
\end{tabular}} \\
\hline Socioeconomic status: Low & 0.849 & $0.328-1.047$ \\
\hline High & 0.772 & $0.357-1.008$ \\
\hline
\end{tabular}

Previous similar studies have confirmed the mentioned significant difference $[27,29,35,48$ 51). A meta-analysis by Shi et al. [48], analyzed the data of PPD in the COPD and non-COPD group of 8 studies [31, 33, 41, 43, 48, 49, 52-
54]. The results showed that probing depth in the COPD patients was deeper than that of the non-COPD group, and the mean difference was $0.261 \mathrm{~mm}$ (95\% CI: 0.020-0.501, $\mathrm{p}=0.033$ ). Because the heterogeneity between the studies 
was high $(\mathrm{I} 2=93.8 \%)$, a random effects model was selected. However, the sensitivity analysis revealed that the results were not stable. Despite the last observation the main finding was that periodontitis condition in the COPD group was more severe than that in the non-COPD group.

In contrary, in a similar report Scannapieco et al. [37] recorded that patients with a history of COPD did not show more PPD index than subjects without COPD.

CAL is another index for assessing the severity of periodontitis [47] and also refers to the long term stages of chronic inflammation including destructive processes signs of a chronic inflammatory response. The present report showed no significant difference between cases and controls regarding that index.

The same meta-analysis [48] recorded that the COPD patients suffered from worse periodontal health status, indicated by high level of CAL. Similar findings were confirmed by other researches [35, 50, 51, 55]. Ban et al. [56] were found that oral health of the cases group was worse than that of the controls and in cases group the mean and maximal CAL, were higher. However, it was not clear whether the COPDassociated systemic inflammation impaired the oral status or the chronic periodontitis influenced negatively chronic obstructive pulmonary disease.

Shi et al. [48], also assessed the data of CAL in COPD and non-COPD individuals from 10 studies [29, 31, 33, 37, 41, 49, 52-54, 57], and found that the COPD patients suffered more CAL compared with the non-COPD subjects. The mean difference was found to be $0.480 \mathrm{~mm}$ (95\% CI: $0.280-0.681$, random effect model, I2 $=89.7 \%$ ), which was of statistical significance $(p=0.000)$, whereas the Egger's test showed that no publication bias was detected $(\mathrm{p}=0.979)$. Moreover, the sensitivity analysis showed that the pooled results were powerful.

BOP index reflects the host's vascular response in terms of hyperemia, the capillaries' dilation and increased blood flow in the inflammation region. BOP is a widely used criterion to diagnose gingival inflammation, however it has been suggested that periodontal pockets with a probing depth of greater than or equal to 5.00 $\mathrm{mm}$ showed a significantly higher incidence of BOP [58]. In the current study no significant difference was observed between cases and controls regarding that index. Similarly,
Scannapieco et al. [37] found no association between gingival bleeding and chronic respiratory disease. In contrary previous studies revealed that COPD patients suffer from worse periodontal health status, indicated by more inflammation and bleeding in the gingival tissue [48, 56]. Deo et al. [29] found that the percentage of individuals with $<20 \%$ bleeding sites was significantly greater in non- COPD individuals(12\% of non- COPD individuals and $4 \%$ of COPD patients).Ina meta-analysis [48] which was assessed BOP [41, 54] and Gingival Bleeding Index (GBI), in the COPD and nonCOPD groups, contrary results were revealed by comprehensive analysis. For the GBI, the mean difference was 0.241 with no statistical significance ( $95 \%$ CI: 0.106 to $0.588, \mathrm{p}=0.173$, random effect model, $\mathrm{I} 2=95.9 \%$ ), whereas the results of $\mathrm{BOP}$ revealed that more bleeding was observed in the COPD (mean difference $=$ 6.878, 95\% CI: $5.489-8.266, p=0.000$, fixed effect model, I $2=0 \%$ ).

It is possible that these different results may be caused by the limited number of studies which use these three indices, which means that more well-designed studies are needed in the future. At last the number of remaining teeth in both groups, or other PD indices, such as PI, ABL could be used for assessing the periodontal status groups examined.

The outcomes of the current study also showed that oral hygiene habits were significantly different between cases and controls and that COPD-individuals had worse oral hygiene. Such outcomes have confirmed from previous similar studies [31, 35, 48, 49, 54, 59].

Only in a study by Parashar et al. [50], was revealed that the frequency of brushing did not show much difference among both groups.

In Europe and North America the prevalence of COPD is $9-10 \%$ in adults aged 40 years or older, observation that has been attributed to increased smoking rates [3]. Despite the fact that older individuals are at higher risk for COPD development [24, 60-67], age is considered as a confounder. Similarly, older individuals are at higher risk for initiation and progression of PD [68].The difference regarding the parameter of age between COPD individuals and non-COPD ones was not statistically significant in the current report.

COPD, nowadays, mainly affects females because smoking prevalence has increased 
among females and may be more susceptible to the adverse pulmonary function effects of smoking than males. Another reason is that unbiased measures of lung function are underused could lead to under and misdiagnosis of COPD in both genders [69-73]. Females may have a greater predisposition to COPD [74], as the prevalence of smoking in females has increased progressively [75]. Moreover, a growing health burden of COPD among females [76] and non-smokers [77] has been suggested over the last few years, because of their exposure to biomass fuels which could lead to COPD development in younger females [77, 78]. In the current study no statistically significant difference was recorded between cases and controls regarding the gender, which is also considered as a confounder.

SES is a risk factor for COPD development [24, $38,79-87]$, however it remains unclear, whether it reflects exposures to cigarette smoke, indoor and outdoor air pollutants, crowding, poor nutrition, or other factors that are related to low SES [16].

COPD patients, have higher age, less income, lower educational level, consumed more tobacco and alcohol, irrespective of whether they suffered from PD or not [88]. The disease is unevenly distributed in the population, as lowest SES individuals who suffer from COPD are more likely to experience poor health outcomes than those of the highest SES COPD patients [87]. The current report showed no statistically difference between COPD and nonCOPD individuals regarding SES, which is another crucial confounder.

COPD-patients have lower education level that non-COPD individuals [79, 83, 88, 89]. Moreover, it has also been proposed that higheducated individuals take care of their own oral hygiene more than low-educated ones and could prevent diseases that are associated with PD [90]. No significant difference was recorded between COPD and non-COPD individuals regarding the educational level in the present research.

Cigarette smoking and passive cigarette smoking is a risk factor for COPD development $[8,9]$, despite the fact that not all cigarette smokers develop clinically significant COPD, suggesting that genetic factors may modify each individual's risk [13], whereas it also remains unclear why individuals-never smokers develop COPD [14].
Smoking is also an important risk factor for PD development and progression [28] and a proven confounder. The association between the two diseases possibly reflects exposure to tobacco smoke [28]. However, it remains unclear whether the susceptibility to tissue destruction that is caused by smoking consists a general individual's characteristic or whether different individual's tissues show different reactions to the harmful effects of smoking. If the sensitivity to smoking is not a general individual characteristic the destructive procedures in periodontal tissues will develop independently of changes in the lungs.

SES, and smoking were the main reason why the Cochran and Mantel-Haenszel model was carried out in an effort to clarify if possible significant differences between COPD and nonCOPD individuals regarding the PD indices examined could be attributed to those epidemiological parameters. The model showed that smoking and SES were not confounders of PPD and the oral hygiene indices. As mentioned few epidemiological studies, mainly metaanalyses and case control studies have investigated possible differences regarding the periodontal status between individuals suffering from COPD compared with healthy individuals and in some cases have led to contradictory outcomes.

Several limitations must be taken into account in the current retrospective case-control study. It is known that case-controls studies are susceptible to selection, recall, random, referral bias and the their outcomes must be adjusted for known and unknown confounders which can to lead to biased secondary associations regarding the indices examined. In contrary, the prospective cohort studies design can control confounding biases. Other limitations of the current study are the fact that COPD and PD share some common risk factors such as smoking and SES, the fact that PD is considered as a risk factor for COPD pathogenesis, the use of questionnaire as such studies are susceptible to response bias as it is possible that the response given is what the individuals consider the socially adequate response, not the real one.

Some strengths of the current study were the large and the representative study sample and that it was a matched case-control study, as was used randomly selected population-based controls as were selected from non-COPD individuals derived from cases environment, 
methodology warrants interval validity. More studies, especially prospective are needed to confirm those findings.

\section{CONCLuSion}

Probing pocket depth and oral hygiene parameters such as tooth-brushing frequency and dental check-up, as periodontal status indices were statistically significant different between individuals who were suffered from COPD and healthy ones.

\section{REFERENCES}

[1] Mannino DM, Homa DM, Akinbami LJ, Ford ES, Redd SC. Chronic obstructive pulmonary disease surveillance-United States,1971-2000. Respir Care. 2002;47:1184-1199.

[2] Rabe KF, Beghé B, Luppi F, Fabbri LM. Update in Chronic Obstructive Pulmonary Disease 2006. Am J RespirCrit Care Med. 2007;175: 1222-1232.

[3] Decramer M, Janssens W, Miravitlles M. Chronic obstructive pulmonary disease. Lancet. 2012;379:1341-1351.

[4] Rabe KF, HurdS, Anzueto A, Barnes PJ,Buist SA, Calverley P, et al. Global strategy for the diagnosis, management and prevention of chronic obstructive pulmonary disease: Gold execu- tive summary. Am J RespirCrit Care Med. 2007;176:532-555.

[5] Stoller JK, Aboussouan LS. Alpha1-antitrypsin deficiency. Lancet. 2005;365:2225-2236.

[6] Blanco I, de Serres FJ, Fernandez-Bustillo E, Lara B, Miravitlles M.Estimated numbers and prevalence of $\mathrm{PI} * \mathrm{~S}$ and $\mathrm{PI} Z \mathrm{Z}$ alleles of alpha1-antitrypsin deficiency in European countries. EurRespir J. 2006;27:77-84.

[7] Silverman EK, Palmer LJ, Mosley JD, Barth M, Senter JM, Brown A, et al. Genomewide linkage analysis of quantitative spirometric phenotypes in severe early-onset chronic obstructive pulmonary disease. Am J Hum Genet. 2002;70:1229-1239.

[8] Jindal SK, Aggarwal AN, Chaudhry K, Chhabra SK, D'Souza GA, Gupta D, et al. A multicentric study on epidemiology of chronic obstructive pulmonary disease and its relationship with tobacco smoking and environmental tobacco smoke exposure. Indian J Chest Dis Allied Sci. 2006;48:23-29.

[9] Eisner MD, BalmesJ, Katz BP, Trupin L, YelinEH, Blanc PD. Lifetime environmental tobacco smoke exposure and the riskof chronic obstructive pulmonary disease. Environ Health. 2005;4:7.

[10] Balmes J, BecklakeM, Blanc P, Henneberger P, KreissK, Mapp C, et al. American Thoracic
Society statement: Occupational contribution to the burden of airway disease. Am J RespirCrit Care Med. 2003;167:787-797.

[11] Oroczo-Levi M. Garcia-Aymerich J, VillarJ, Ramírez-Sarmiento A, Antó JM, GeaJ. Wood smoke exposure and risk of chronic obstructive pulmonary disease. EurRespir J. 2006;27:542 546.

[12] Sezer H, AkkurtI, Guler N, Marakoğlu K, Berk S.A case-control study on the effect of exposure to different substances on the development of COPD. Ann Epidemiol. 2006;16:59- 62.

[13] Smith CA, Harrison DJ. Association between polymorphism in gene for microsomal epoxidehydrolase and susceptibility to emphysema. Lancet. 1997;350:630-633.

[14] Birring SS, Brightling CE, Bradding P,Entwisle JJ, Vara DD, Grigg J, et al. Clinical, radiologic, and induced sputum features of chronic obstructive pulmonary disease in nonsmokers: A descriptive study. Am J RespirCrit Care Med. 2002;166:1078-1083.

[15] Prescott E, Lange P, Vestbo J. Socioeconomic status, lung function and admission to hospital for COPD: Results from the Copenhagen City Heart Study. EurRespir J. 1999;13:1109- 1114.

[16] U.S. Centers for Disease Control and Prevention. Criteria for a recommended standard: occupational exposure to respirable coal mine dust. Atlanta, GA: National Institute of Occupational Safety and Health;1995, pp.1428.

[17] Giovino GA, Mirza SA, Samet JM, Gupta PC, Jarvis MJ, Bhala $\mathrm{N}$, et al. Tobacco use in 3 billion individuals from 16 countries: an analysis of nationally representative crosssectional household surveys. Lancet. 2012;380:668-679.

[18] Hogg JC. Pathophysiology of airflow limitation in chronic obstructive pulmonary disease. Lancet. 2004;364:709721.

[19] Pihlstrom BL, Michalowicz BS, Johnson NW. Periodontal diseases. Lancet. 2005;366: 18091820.

[20] Renvert S, Lindahl C, Roos-Jansåker AM, Lessem J. Short-term effects of an antiinflammatory treatment on clinical parameters and serum levels of c-reactive protein and prion-flammatory cytokines in subjects with periodontitis. J Periodontol. 2009;80:892-900.

[21] Vidal F, Figueredo CM, Cordovil I, Fischer RG. Periodontal therapy reduces plasma levels of interleukin-6, C-reactive protein, and fibrinogen in patient with a severe periodontitis and refractory arterial hypertension. J Periodontol. 2009;80:786-791. 
[22] Cullinan MP, Ford PJ, Seymour GJ. Periodontal disease and systemic health: current status. Aust Dent J. 2009;54:S62-69.

[23] Azarpazhooh A, Leake JL. Systematic review of the association between respiratory diseases and oral health. J Periodontol. 2006;77:14651482.

[24] Scannapieco FA, Bush RB, Paju S. Associations between periodontal disease and risk for nosocomial bacterial pneumonia and chronic obstructive pulmonary disease. A systematic review. Ann Periodontol. 2003;8:5469.

[25] Chrysanthakopoulos NA, Chrysanthakopoulos PA. Examination of the relation between periodontal disease parameters and chronic obstructive pulmonary disease: A case-control study in Greek adults. Case Rep Rev Open Access. 2020;1(1):108

[26] Hyman JJ, Reid BC. Cigarette smoking, periodontal disease, and chronic obstructive pulmonary disease. J Periodontol. 2004;75: 915.

[27] Kowalski M, Kowalska E, Split M, Split W, Wierzbicka-Ferszt A, Pawlicki L, et al. Assessment of periodontal state in patients with chronic obstructive pulmonary disease--part II. Pol MerkurLekarski. 2005 ;19:537-541.

[28] Leuckfeld I, Obregon-Whittle MV, Lund MB, Geiran O, BjørtuftØ, Olsen I. Severe chronic obstructive pulmonary disease: Association with marginal bone loss in periodontitis. RespirMed. 2008;102:488-494.

[29] Deo V, Bhongade ML, Ansari S, Chavan RS. Periodontitis as a potential risk factor for chronic obstructive pulmonary disease: a retrospective study. Indian $\mathbf{J}$ DentRes. 2009;20:466 -470.

[30] Fatemi K, Banihashemrad S, Tovhidi M, Sayed Hossein H. Evaluation of the Relationship Between Periodontal Disease and Chronic Obstructive Pulmonary Disease.J Mash DentSch. 2009; 33:214-266.

[31] Wang Z, Zhou X, Zhang J, Zhang L, Song Y, $\mathrm{Hu}$ FB, et al. Periodontal health, oral health behaviors, and chronic obstructive pulmonary disease. J ClinPeriodontol. 2009;36:750-755.

[32] Prasanna SJ. Causal relationship between periodontitis and chronic obstructive pulmonary disease. J Indian SocPeriodontol. 2011;15:359-365.

[33] Si Y, Fan H, Song Y, Zhou X, Zhang J, Wang $Z$. Association between periodontitis and chronic obstructive pulmonary disease in a Chinese population. J Periodontol. 2012;83:1288- 1296.

[34] Zhou X, Han J, Song Y, Zhang J, Wang Z. Serum levels of 25-hydroxyvitamin D, oral health and chronic obstructive pulmonary disease. J ClinPeriodontol. 2012;39:350-356.

[35] Sharma N, ShamsuddinH. Association between respiratory disease in hospitalized patients and periodontal disease: A cross-sectional study. J Periodontol. 2011;82:1155-1160.

[36] Liu Z, Zhang W, Zhang J, Zhou X, Zhang L, Song Y, et al. Oral hygiene, periodontal health and chronic obstructive pulmonary disease exacerbations. JClinPeriodontol. 2012;39:4552.

[37] Scannapieco FA, Ho AW. Potential associations between chronic respiratory disease and periodontal disease: analysis of National Health and Nutrition Examination Survey III. J Periodontol. 2001;72:50-56.

[38] Hobbins S, Chapple IL, Sapey E, Stockley RA. Is periodontitis a comorbidity of COPD or can associations be explained by shared risk factors/behaviors? Int J Chron Obstruct Pulmon Dis. 2017;12:1339-1349.

[39] Usher AK, Stockley RA. The link between chronic periodontitis and COPD: a common role for the neutrophil? BMC Med.2013; 11:241.

[40] Zeng XT, Tu ML, Liu DY, Zheng D, Zhang J, Leng W. Periodontal disease and risk of chronic obstructive pulmonary disease: a metaanalysis of observational studies. PLOS ONE. 2012;7:e46508.

[41] Yildirim E, Kormi I, Basoglu OK, Gurgun A, Kaval B, Sorsa T, et al. Periodontal health and serum, saliva matrix metalloproteinases in patients with mild chronic obstructive pulmonary disease. J Periodont Res. 2013;48:269-275

[42] Terashima $\mathrm{T}$, Chubachi S, Matsuzaki T, Nakajima T, Satoh M, Iwami E, et al. The association between dental health and nutritional status in chronic obstructive pulmonary disease. ChronRespir Dis 2016;14: 334-341.

[43] Zhou X, Wang J, Liu W, Huang X, Song Y, Wang Z, et al. Periodontal Status and Microbiologic Pathogens in Patients with Chronic Obstructive Pulmonary Disease and Periodontitis: A Case-Control Study.Int J Chron Obstruct Pulmon Dis 2020:15: 271-279.

[44] Tonetti MS, Greenwell H, Kornman KS. Staging and grading of periodontitis: framework and proposal of a newclassification and case definition. JClinPeriodontol.2018;45 :S149- S161.

[45] Peikert SA, Mittelhamm F, Frisch E, Vach K, Ratka Krüger P, Woelber JP. Use of digital periodontal data to compare periodontal treatment outcomes in a practice-based research network (PBRN): a proof of concept. BMC Oral Health. 2020; 20:297. 
[46] Page RC, Eke PI. Case definitions for use in population based surveillance of periodontitis. JPeriodontol. 2007;78:1387-1399.

[47] Zimmermann H, Hagenfeld D, Diercke K, ElSayed N, Fricke J, Greiser KH, et al. Pocket depth and bleeding on probing and their associations with dental, lifestyle, socioeconomic and blood variables: a crosssectional, multicenter feasibility study of the German National Cohort. BMC Oral Health. 2015, 15:7.

[48] Shi Q, Zhang B, XingH, YangS, Xu J, LiuH. Patients with Chronic Obstructive Pulmo- nary Disease Suffer from Worse Periodontal HealthEvidence from a Meta-Analysis. Front Physiol. 2018;9:33.

[49] BhavsarNV, Dave BD, Brahmbhatt NA, Parekh R. Periodontal status and oral health behavior in hospitalized patients with chronic obstructive pulmonary disease. J Nat SciBiol Med. 2015; 6: S93-S97.

[50] Parashar P, ParasharA, Saraswat N, Pani P, Pani N, Joshi S. Relationship between Respiratory and Periodontal Health in Adults: A Case-Control Study. JIntSocPrev Community Dent. 2018; 8(6): 560-564.

[51] BombleN, Shetiya SH, Agarwal DR. Association of periodontal status with lung function in patients with and without chronic obstructive pulmonary disease visiting a medical hospital in Pune: A comparative study. JIndianSocPeriodontol. 2020; 24: 67-71.

[52] Ledic K, Marinkovic S, Puhar I, Spalj S, Popovic-Grle S, Ivic'-Kardum $M$, et al. Periodontal disease increases risk for chronic obstructive pulmonary disease. CollAntropol. 2013;37: 937-942.

[53] Peter KP, Mute BR, Doiphode SS, Bardapurkar SJ, Borkar MS, Raje, DV. Association between periodontal disease and chronic obstructive pulmonary disease: a reality or just a dogma? JPeriodontol. 2013;84:17171723.

[54] Öztekin G, Baser U, Kucukcoskun M, Tanrikulu-Kucuk S, Ademoglu E, Isik G, et al. The association between periodontal disease and chronic obstructive pulmonary disease: a case control study. COPD2014;11:424-430.

[55] Tan L, Tang X, Pan C, Wang H, Pan Y. Relationship among clinical periodontal, microbiologic parameters and lung function in participants with chronic obstructive pulmonary disease. J Periodontol. 2019;90:134-140.

[56] Bán A , Németh ZF, Szauter A, Soós S, Balaskó M. Prevalence and severity of chronic parodontitis and oral mucosal lesions in chronic obstructive lung disease. OrvHetil. 2018;159: 831-836.
[57] Vadiraj S, Nayak R, Choudhary GK, Kudyar N, Spoorthi BR. Periodontal pathogens and respiratory diseases-evaluating their potential association: a clinical and microbiological study. J Contemp Dent Pract 2013;14:610-615.

[58] Lang NP, JossA, Orsanic T, GusbertiFA, Siegrist BE.Bleeding on probing. A predictor for the progression of periodontal disease?J ClinPeriodontol.1986;13: 590-596.

[59] Chung JH, Hwang HJ, Kim SH, Kim TH. Associations between Periodontitis and Chronic Obstructive Pulmonary Disease: The 2010 to 2012 Korean National Health and Nutrition Examination Survey. J Periodontol. 2016;87):864-871.

[60] VazFragoso CA, Gill TM, McAvay G , Van Ness PH, Yaggi HK, Concato J. Evaluating respiratory impairment in middle- aged persons using lambda-mu-sigma derived z-scores. Respir Care. 2011; 56:1771-1777.

[61] VazFragoso CA, Gill TM, McAvay G, Yaggi HK, Van Ness PH, Concato J. Respiratory impairment and mortality in older persons: a novel spirometricapproach. J Investig Med. 2011; 59(7): 1089-1095.

[62] Regan EA, Hokanson JE, Murphy JR, Make B, Lynch DA, Beaty TH, et al. Genetic epidemiology of COPD (COPDGene) study design. COPD 2010; 7(1):32-43.

[63] VazFragoso CA, McAvay G, Van Ness PH, Casaburi R, Jensen RL, MacIntyre N, et al. Phenotype of normal spirometryinan aging population. Am J RespirCritCare Med. 2015; 192: 817-825.

[64] Stanojevic S, Wade A, Stocks J, Hankinson J, Coates AL, Pan H, et al. Reference ranges for spirometry across all ages: a new approach. Am J RespirCrit Care Med. 2008;177:253-260.

[65] Quanjer PH, Stanojevic S, Cole TJ, Baur X, Hall GL, Culver BH, et al. Multi-ethnic reference values for spirometry for the 3-95 year age range: the global lung function 2012 equations. EurRespir J. 2012;40: 1324-1343.

[66] VazFragoso CA, Gill TM, McAvayG, Quanjer $\mathrm{PH}$, Van NessPH, Concato J. Respiratory impairment in older persons: when less means more. Am J Med. 2013; 126:49-57.

[67] MacNee W. Is Chronic Obstructive Pulmonary Disease an Accelerated Aging Disease? Ann Am Thorac Soc. 2016;13:S429-S437.

[68] Carranza FA. Epidemiology of gingival and periodontal diseases. In: Newmann MG, Takei HH, Carranza F, editor. Text Book of Carranza's Clinical Period Ontology. St Louis.Mis- souri: Saunders; 2006. p. 86-91

[69] Chapman KR, Tashkin DP, Pye DJ. Gender bias in the diagnosis of COPD. Chest. 2001;119: 1691-1695. 
[70] Sørheim IC, Johannessen A, Gulsvik A, Bakke PS, Silverman EK, DeMeo DL. Gender differences in COPD: are women more susceptible to smoking effects than men? Thorax. 2010; 65:480-485.

[71] Gan WQ, Man SF, PostmaDS, CampP, SinDD. Female smokers beyond the perimenopausal period are at increased risk of chronic obstructive pulmonary disease: a systematic review and meta-analysis. Respir Res. 2006;7:52.

[72] Prescott E, Bjerg AM, Andersen PK, P Lange, J Vestbo. Gender difference in smoking effects on lung function and risk of hospitalization for COPD: results from a Danish longitudinal population study. EurRespir J. 1997;10:822-827.

[73] Barnes PJ. Sex Differences in Chronic Obstructive Pulmonary Disease Mechanisms. Am J RespirCrit Care Med. 2016;193:813-824.

[74] Buist AS, McBurnie MA, Vollmer WM, Gillespie S, Burney P, Mannino DM, et al. International variation in the prevalence of COPD (the BOLD Study): A population-based prevalence study. Lancet. 2007;370:741-750.

[75] Mannino DM, Buist AS. Global burden of COPD: risk factors, prevalence, and future trends. Lancet. 2007; 370:765-773.

[76] Jenkins CR, Chapman KR, Donohue JF, Roche N, Tsiligianni I, Han MK. Improving the management of COPD in women. Chest. 2017;151:686-696.

[77] Salvi SS, Barnes PJ. Chronic obstructive pulmonary disease in non-smokers. Lancet. 2009; 374:733-743.

[78] van Schayck OCP, BoudewijnsEA. COPD and asthma: The emergency is clear, now is the time for action. Lancet Respir Med. 2017;5:668-679.

[79] Prasanna SJ. Causal relationship between periodontitis and chronic obstructive pulmonary disease. J Indian SocPeriodontol. 2011;15:359-365.

[80] Prescott E, Godtfredsen N, Vestbo J, Osler M. Socialposition and mortality from respiratorydiseases in males and females. EurRespir J. 2003;21: 821-826.

[81] KoefoedM, Sondergaard J, Christensen R, Jarbøl DE. Influence of socioeconomic and demographic status on spirometry testing in patients initiating medication targeting obstructive lung disease: a population-based cohort study. BMC Public Health. 2013;13: 580.

[82] Lange P, Marott JL, Vestbo J, Ingebrigtsen TS, Nordestgaard BG. Socioeconomic status and prognosis of COPD in Denmark. COPD. 2014; 11:431-437.

[83] Halvorsen T, Martinussen PE. The Geography of Chronic Obstructive Pulmonary Disease: A Population-Based Study of Norway. Soc Sci Med. 2014;111:25-34

[84] Peng Y, Mei Z, Yichong L, Yong J, Wenhua Z. Prevalence of COPD and its association with socioeconomic status in China: Findings from China Chronic Disease Risk Factor Surveillance 2007. BMC Public Health. 2011;11:586

[85] Xu F, Yin X, Zhang M, Shen HB, Lu LG, Xu YC. Prevalence of physician-diagnosed COPD and its association with smoking among urban and rural residents in regional main- land China. Chest. 2005;128:2818-2823.

[86] Chan-YeungM, Ho AS, Cheung AH, Liu RWT, Yee WKS, Sin KM, et al. Determinants of chronic obstructive pulmonary disease in Chinese patients in Hong Kong. Int J Tuberc Lung Dis. 2007;11:502-507.

[87] Gershon AS, Dolmage TE, Stephenson A, Jackson B. Chronic obstructive pulmonary disease and socioeconomic status: a systematic review. COPD. 2012;9:216-226.

[88] Kim SW, Han K, Kim SY, Park CK, Rhee CK, Yoon HK. The relationship between the number of natural teeth and airflow obstruction: a cross-sectional study using data from the Korean National Health and Nutrition Examination Survey. IntJChronObstructPulmon Dis. 2016; 11:13-21.

[89] Bakke PS, Hanoa R, Gulsvik A. Educational level and obstructive lung disease given smoking habits andoccupational airborne exposure: a Norwegian community study. Am J Epidemiol. 1995;141:1080-1088

[90] Astrøm AN, Rise J. Socio-economic differences in patterns of health and oral health behaviour in 25 year old Norwegians. Clin Oral Investig. 2001;5:122-128

Citation: Nikolaos Andreas Chrysanthakopoulos, Aggelos Antonios Oikonomou. Examination of Periodontal Status in Chronic Obstructive Pulmonary Disease Greek Adults: A Case - Control Study. ARC Journal of Dental Science. 2020; 5(4):1-11. DOI: https://doi.org/10.20431/2456-0030.0504001.

Copyright: (C) 2020 Authors. This is an open-access article distributed under the terms of the Creative Commons Attribution License, which permits unrestricted use, distribution, and reproduction in any medium, provided the original author and source are credited. 